\title{
ハイブリッドリポソームを用いたアルツハイマー病治療に関する基礎研究
}

座古恵子, 坂口磨姫, 古水雄志, 市原英明,

後藤浩一，松本陽子，上岡龍一*

\section{Experimental Therapeutic Effects of Hybrid Liposomes on the Alzheimer's Disease in Vitro}

\author{
Keiko ZAKo, Maki SAKAGUCHI, Yuji KOMIZU, Hideaki ICHIHARA, \\ Koichi Goto, Yoko MATSUMOTO, and Ryuichi UEOKA* \\ Division of Applied Life Science, Graduate School of Engineering, Sojo University, \\ 4-22-1 Ikeda, Kumamoto 860-0082, Japan
}

(Received January 10, 2011; Accepted February 21, 2011; Published online February 24, 2011)

\begin{abstract}
Accumulation of $\beta$ amyloid (A $\beta$ ) peptides to nerve cells should be associated with the onset of Alzheimer's disease (AD). We prepared hybrid liposomes (HL) composed of $90 \mathrm{~mol} \%$ phospholipids having various charged head groups (cationic L- $\alpha$-dimyristoyltrimethyl ammonium propane (DMTAP), anionic L- $\alpha$-dimyristoylphosphatidylserine (DMPS) or zwitterionic L- $\alpha$-dimyristoylphosphatidylcholine (DMPC) ) and $10 \mathrm{~mol} \%$ polyoxyethylene (23) dodecyl ether $\left.\left(\mathrm{C}_{12}(\mathrm{EO})_{23}\right)\right)$, and investigated the inhibitory effects of $\mathrm{HL}$ on the accumulation of $\mathrm{A} \beta_{1-40}$ peptides into human neuroblastoma (SH-SY5Y) cells in vitro. It is noteworthy that remarkable inhibitory effects on the accumulation of $\mathrm{A} \beta_{1-40}$ peptides were observed for SH-SY5Y cells treated with anionic HL-DMPS, though the accumulation was not inhibited by cationic HL-DMTAP. On the other hand, the immediate fusion of HL-DMTAP into SH-SY5Y cells was confirmed using a confocal laser microscope. Interestingly, the specific interactions between anionic HL-DMPS and A $\beta_{1-40}$ peptides were observed using the thioflavin $\mathrm{T}$ (ThT) assay. In addition, the cytotoxicity of $\mathrm{A} \beta_{1-42}$ peptides on the SHSY5Y cells decreased after the treatment with HL-DMPS. These results suggest that anionic HL-DMPS could be used as a novel medicine for $\mathrm{AD}$ in the future.
\end{abstract}

Key words_— Alzheimer's disease; amyloid $\beta$; hybrid liposome

\section{緒言}

アルツハイマー病 (Alzheimer's disease: AD) は, 痴呆を主な症状とし, 脳の萎縮・アミロイドの沈着 による老人斑・神経細胞死がみられる世界的に最も 多い進行性の神経変性疾患である. 現在, 国内にお ける患者数は 200 万人を超えており，社会の高齢化 に伴って，その数は増加していくと予想されている. AD には, 常染色体優勢遺伝の家族性 AD (Familial $\mathrm{AD}: \mathrm{FAD})$ と環境的要因を背景に持った弧発性 $\mathrm{AD}$ に大別される。両方の発症率を比較すると, FAD は全体の数\%に過ぎず，大多数が弧発性 $\mathrm{AD}$ である。しかしながら, 弧発性 $\mathrm{AD}$ の根本的な原 因はいまだ明らかにされていない.

$\mathrm{AD}$ 発症の原因として広く研究されているのは,

崇城大学大学院工学研究科応用生命科学専攻

*e-mail: ueoka@life.sojo-u.ac.jp
ペプチドの一種である $\beta$ アミロイド $(\mathrm{A} \beta)$ の蓄積 に注目したアミロイドカスケード仮説に関する研究 である. ${ }^{1)} \mathrm{A} \beta$ は，アミロイド前駆体タンパク質 (APP) が, セクレターゼによって切断されて産生 される，38 から43 のアミノ酸からなるペプチドで ある。また，APPより産生された A $\beta$ の異常凝集 によるアミロイド塊が，神経毒性を持つことが知ら れている. ${ }^{2)}$ 凝集体を形成する $\mathrm{A} \beta$ の中でも，40の アミノ酸からなる $\mathrm{A} \beta_{1-40}, 42$ のアミノ酸からなる $\mathrm{A} \beta_{1-42}$ が細胞毒性に梁く係わると言われている。こ れら $\mathrm{A} \beta$ の凝集について, 神経細胞膜上のガングリ オシド（GM1）と結合することで凝集が始まり， 線維形成につながる “seed 仮説”3)が唱えられてお り， $\mathrm{A} \beta$ の挙動が注目されている。 また, 細胞内微 小管の安定化に係わる Tau タンパク質の過剩なリ ン酸化もみられ，これによって神経原線維変化や老 人斑が生じ，神経毒性を示すことも知られている. 
現在， $\mathrm{AD}$ 治療薬として，国内ではアリセプト (ドネペジル塩酸塩) ${ }^{4)}$ が唯一保険適応を持った薬剤 として用いられている. 効能としては, 認知症状の 進行を遅らせる働きがある。しかし，AD の初期段 階での夕作用し，適応範囲が狭い。また，吐き気や 動悸，横紋筋融解症などの副作用も報告されている ため, より安全で治療効果の高い薬剤の開発が急務 である。

上岡らが創製したハイブリッドリポソーム

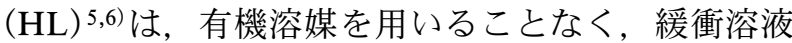
中でリン脂質のようなベシクル分子とミセル分子を 超音波照射するだけで調製できるナノ粒子であり， 「素材や組成比，イオン強度の選択によって膜直径 や相転移温度，流動性といつた物性を制御できる」 特徵がある. ${ }^{5,6)}$ 現在までの HL 研究において, HL にペプチド触媒を含有させた膜酵素モデル研究では,

$\mathrm{L}$ 体アミノ酸エステルのみの立体選択的加水分解に 成功している. ${ }^{7)}$ また，がん治療に関する研究では, in vitro において，薬物を含有させずに種々のがん 細胞に対する顕著な増殖抑制効果を示してい る8,9).さらに，HL はがん細胞膜特異的に蓄積 し, ${ }^{10)}$ カスペースカスケードを経てアポトーシスを 誘導することが明らかになっている. ${ }^{11,12)}$ 薬物運搬 体に関しては，脳腫瘍治療薬である脂溶性ニトロソ ウレア (BCNU) 13) を HL に含有させ，in vivoにお いて，脳腫瘍モデルラットの延命効果を報告してい る. in vivoにおいては，種々の担がんモデルマウ スを用いた治療実験から延命効果が得られてい る. ${ }^{14-16)}$ さらに, 生命倫理委員会の承認後, 悪性リ ンパ腫の患者に対する臨床試験において，高い安全 性及び固形リンパ腫瘍の顕著な縮小効果が得られて いる. ${ }^{16)}$ 一方, 最近, in vitro におけるヒト末梢血 単核細胞に対する免疫賦活効果も報告されてお り, ${ }^{17)}$ 生体適合性の優れた医用素材として期待され ている.

本研究は， $\mathrm{AD}$ モデル細胞として用いられている ヒト神経芽腫（SH-SY5Y）細胞を使用し，親水基 の電荷の異なる脂質を素材とする HL を用いて, $\mathrm{A} \beta_{1-40}$ 蓄積抑制効果並びにメカニズムについて検討 した.

\section{実 験 方 法}

1. 試料 双性リン脂質の L- $\alpha$-ジミリストイル
ホスファチジルコリン $(\mathrm{DMPC})$, アニオン性の L- $\alpha$-ジミリストイルホスファチジルセリン (DMPS) は，市販品（日本油脂）をそのまま使用した，同様 に，カチオン性の 1,2-ジミリストイル-3-トリメチ ルアンモニウムプロパン (DMTAP) も，市販品 （Avanti Polar Lipids）を使用した。PEG 系界面活 性剤であるポリオキシエチレン(23) ドデシルエー テル $\left(\mathrm{C}_{12}(\mathrm{EO})_{23}\right)$ は，市販品（Sigma）を Elworthy らの方法 ${ }^{18)}$ に従い，エーテル再結晶したものを 用いた．Figure 1 に素材に用いたリン脂質の構造式 を示す。蛍光脂質である 1-パルミトイル-2-[12-[ (7ニトロ-2-1,3-ベンゾキシアジアゾール-4-イル) アミ ノ］ドデカノイル]-sn-グリセロ-3-ホスフォコリン (NBDPC) は，市販品（Avanti Polar Lipids）をそ のまま使用した。

\section{2. 細胞 ヒ上神経芽腫 (SH-SY5Y, ATCC)} 細胞を実験に用い，RPMI1640（Gibco）にペニシ リン $\mathrm{G}$ 及び硫酸ストレプトマイシン (明治製菓), 20\%ウシ胎児血清（HyClone）を含有させたものを 培地として, $37^{\circ} \mathrm{C}, 5 \% \mathrm{CO}_{2}$ 下で培養した。

3. ハイブリッドリポソームの調製ＨL は, $90 \mathrm{~mol} \%$ リン脂質（DMPC, DMPS, DMTAP）と $10 \mathrm{~mol} \% \mathrm{PEG}$ 系界面活性剂（ $\left.\mathrm{C}_{12}(\mathrm{EO})_{23}\right)$ をリン 酸緩衝溶液 $(\mathrm{PBS}(-))$ に溶解させ， $45^{\circ} \mathrm{C}$ ，窒素雰 囲気下で超音波照射して調製した。 孔径 $0.20 \mu \mathrm{m}$ メ ンブレンフィルターでろ過滅菌したものを実験に使 用した。

4. ハイブリッドリポソームの膜直径の測定 $\mathrm{HL}$ の膜直径 $\left(d_{\mathrm{hy}}\right)$ は, 光散乱光度計 (ELSZ-0, Otsuka Electronics）を用い, 動的光散乱法により $25^{\circ} \mathrm{C}$ の条件で測定した。光源として，He-Neレー ザーの $633 \mathrm{~nm}$ の発振線を出力 $10 \mathrm{~mW}$ で用い, 散 乱角 $90^{\circ}$ で測定し，得られた拡散係数 $(D)$ から Stokes-Einstein 式 Eq. (1)に従って, $d_{\text {hy }}$ を求めた.

$$
d_{\mathrm{hy}}=\kappa T / 3 \pi \eta \boldsymbol{D}
$$

ここで, $\kappa$ は Boltzmann 定数, $T$ は絶対温度, $\eta$ は溶媒粘度である。

\section{5. 細胞増殖抑制効果の評価 SH-SY5Y 細胞} に対する $10 \%$ 増殖抑制濃度 $\left(\mathrm{IC}_{10}\right)$ は, 酵素活性 測定法である WST-8 assay (Cell Counting Kit, Dojindo Laboratolies）により評価した. ${ }^{19)} 96$ 穴マルチ プレート（SUMILON）に，初期細胞数 $2.0 \times 10^{5}$ cells $/ \mathrm{ml}$ の細胞懸濁液を $100 \mu \mathrm{l}$ 播種し， $37^{\circ} \mathrm{C}, 5 \%$ 

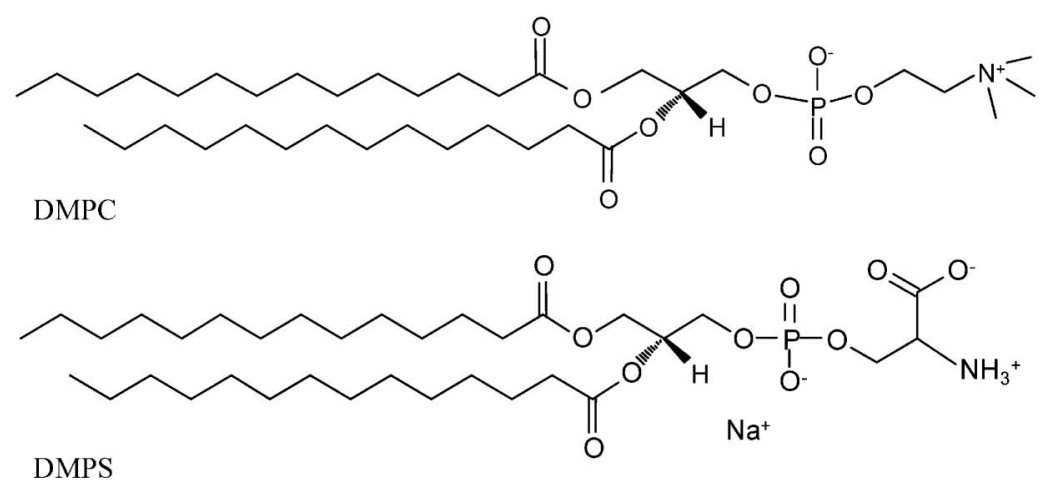

DMPS

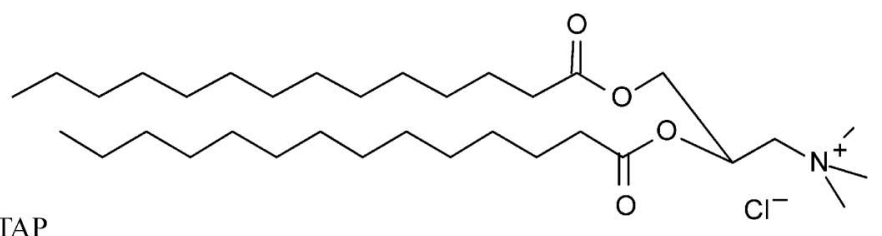

DMTAP

Fig. 1. Molecular Structure of Various Charged Lipids

$\mathrm{CO}_{2}$ 下で 24 時間培養した。試料溶液を $10 \mu \mathrm{l} /$ well 添加し，48 時間培養した。WST-8 溶液を $10 \mu \mathrm{l} /$ well 添加した. 2 時間後に, 分光光度計 (VERSA max microplate reader, Molecular Devices) を用い て，波長 $450 \mathrm{~nm}$ における吸光度を測定した。ここ で，本実験では，HLを添加したものを陽性対象検 体，細胞懸濁液のみのものを陰性対象検体とした. 陽性対象検体の吸光度からブランクの吸光度を引い たものを $A_{\text {Mean }}$, 陰性対象検体の吸光度からブラン クの吸光度を引いたものを $A_{\mathrm{Control}}$ とし, 細胞生存 率を計算した。細胞生存率は, $\left(A_{\text {Mean }} / A_{\text {Control }} \times 100\right.$ \%)により算出し，生存率の試料濃度依存性から $\mathrm{IC}_{10}$ を求めた.

6. 蛍光染色法による A $\boldsymbol{\beta}$ の SH-SY5Y 細胞に対 する蓄積観察 $\quad \mathrm{HL}$ 処理した細胞への $\mathrm{A} \beta_{1-40}$ の蓄 積を，共焦点レーザー顕微鏡（TCS-SP, Leica）を 用いて観察した。ガラスボトムディッシュ（Mat Tek）に, 初期細胞数 $2 \times 10^{5}$ cells $/ \mathrm{ml}$ で細胞を播種 し， $37^{\circ} \mathrm{C}, 5 \% \mathrm{CO}_{2}$ 下で 24 時間培養した。細胞に, $\mathrm{HL}$ 試料溶液及び $\mathrm{A} \beta$ を染色する Thioflavin T （ThT, Wako）を添加して 10 分間インキュベート 後, $\mathrm{A} \beta_{1-40}$ (Peptide Institute) を添加し，90 分間観

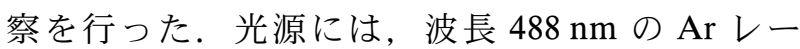
ザーを用い，励起波長 $455 \mathrm{~nm}$ ，検出波長 465-520 $\mathrm{nm}$ の条件で観察した.

7. 細胞へのハイブリッドリポソームの取り込み 量の測定蛍光標識リン脂質の NBDPC を用い,
NBDPC を含有させた HL/NBDPC のSH-SY5Y 細 胞への取り込み量を，フローサイトメーター（Epics XL system II, Beckman Coulter) を用いて測定し た. 初期細胞数 $2 \times 10^{5}$ cells $/ \mathrm{ml}$ の SH-SY $5 Y$ 細胞を, 6 穴プレート（SUMILON）に播種し， $37^{\circ} \mathrm{C}, 5 \%$ $\mathrm{CO}_{2}$ 下で 24 時間培養した。 $\mathrm{HL} / \mathrm{NBDPC}$ 試料溶液 を添加後, 処理時間毎に培養液を除去した後, 細胞 を剥離し，遠心分離にて細胞を回収した。ナイロン メッシュを通過させた後に，FACS チューブに細胞 懸濁液を分注し，フローサイトメーターを用いて測 定した. 光源には, 波長 $488 \mathrm{~nm}$ の Ar レーザーを出 力 $15 \mathrm{~mW}$ で使用し， FL-1 センサーによる NBDPC の蛍光強度の検出を行った。本実験で使用した NBDPC の構造式を Fig. 2 に示す.

8. ThT assay を用いたハイブリッドリポソーム 処理による $\mathrm{A} \beta$ 凝集の測定 $\mathrm{A} \beta$ 凝集体形成に対 する HL の影響を検証するために, $\mathrm{A} \beta$ 指向性色素 である Thioflavin $\mathrm{T}$ (ThT) を用いて分光学的に評 価した. $\mathrm{HL}$ 試料溶液と $\mathrm{A} \beta_{1-40}$ を混合し， $37^{\circ} \mathrm{C}$ で 2 時間インキュベートした後， $1 \mathrm{~cm}$ 角の石英セルに 分注した。 ThT (Nacalai tesque) を添加し，分光 蛍光光度計（F-2000, HITACHI）を用いて，励起 波長 $445 \mathrm{~nm}$ ，蛍光波長 $481 \mathrm{~nm}^{20}$ ) で蛍光強度を測 定した.

9. HL 処理による $\mathbf{A} \boldsymbol{\beta}_{1-42}$ の細胞毒性の測定 $\mathrm{HL}$ 処理が $\mathrm{A} \beta$ の細胞毒性に与える影響について,

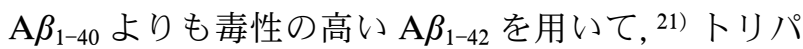




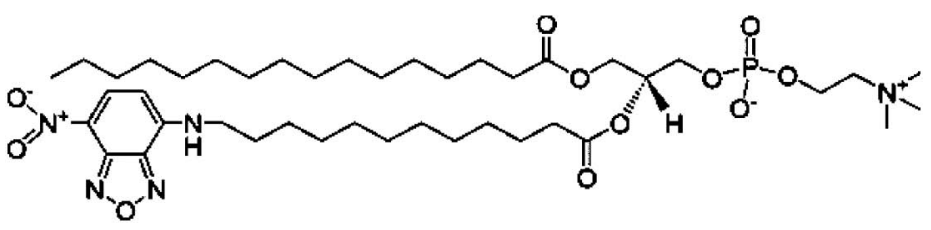

Fig. 2. Molecular Structure of NBDPC

ンブルー色素排除法によって検討した.96 穴マル チプレートに, 初期細胞数 $2.0 \times 10^{5}$ cells $/ \mathrm{ml}$ の SHSY5Y 細胞を $100 \mu \mathrm{l}$ 播種し, $37^{\circ} \mathrm{C}, 5 \% \mathrm{CO}_{2}$ 下で 24 時間培養した。 $\mathrm{HL}$ 試料溶液を添加し, 10 分間イ ンキュベート後, $\mathrm{A} \beta_{1-42}$ を添加して 48 時間培養し た. ウェル内の細胞を回収し，トリパンブルー色素 排除法により細胞数を計測した.

\section{結 果と考察}

1. ハイブリッドリポソームの物性＼cjkstart親水基の 電荷の異なる脂質を構成成分とする HL の膜直径 $\left(d_{\mathrm{hy}}\right)$ の経時変化を, Fig. 3 に示す。双性の HLDMPC 及びアニオン性の HL-DMPS は，100 nm 付近で長期間安定したのに対し，カチオン性の HL-DMTAP は調製直後から不安定であり，短期間 で沈殿を生じた。HL-DMPC 及び HL-DMPS は, 生体内に投与した際に，細網内皮系 ${ }^{22)}$ 回避でき， 臨床応用に適していると考えられる.

2. SH-SY5Y 細胞に対するハイブリッドリポ ソームの増殖抑制効果種々の HL のヒト神経 芽腫 $(\mathrm{SH}-\mathrm{SY} 5 \mathrm{Y})$ 細胞に対する増殖抑制効果 $\left(\mathrm{IC}_{10}\right.$ 值）を，Table 1 にまとめた。なお， $\mathrm{IC}_{10}$ 值は，リ ン脂質濃度を基準とした。双性の HL-DMPCの

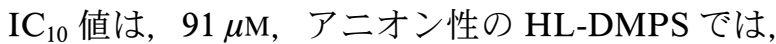
$149 \mu \mathrm{M}$ ，力チオン性の HL-DMTAP の場合は, 54 $\mu \mathrm{M}$ であった。この結果から， $\mathrm{IC}_{10}$ は HL-DMPS> HL-DMPC >HL-DMTAP の順となり, カチオン性 HL-DMTAP は低濃度で細胞増殖を抑制することが 明らかになった。以降は, すべての HL の $\mathrm{IC}_{10}$ 值 以下である $[$ lipids $]=50 \mu \mathrm{M}$ の濃度条件で，実験を 行った.

3. 蛍光染色法による A $\boldsymbol{\beta}_{1-40}$ の SH-SY5Y 細胞へ の蓄積観察 HL 処理による SH-SY5Y 細胞への $\mathrm{A} \beta_{1-40}$ の蓄積抑制効果については， $\mathrm{A} \beta$ を染色する 蛍光色素の Thioflavin $\mathrm{T}$ (ThT) を用いて, 共焦点 レーザー顕微鏡観察により行った。結果を Fig. 4

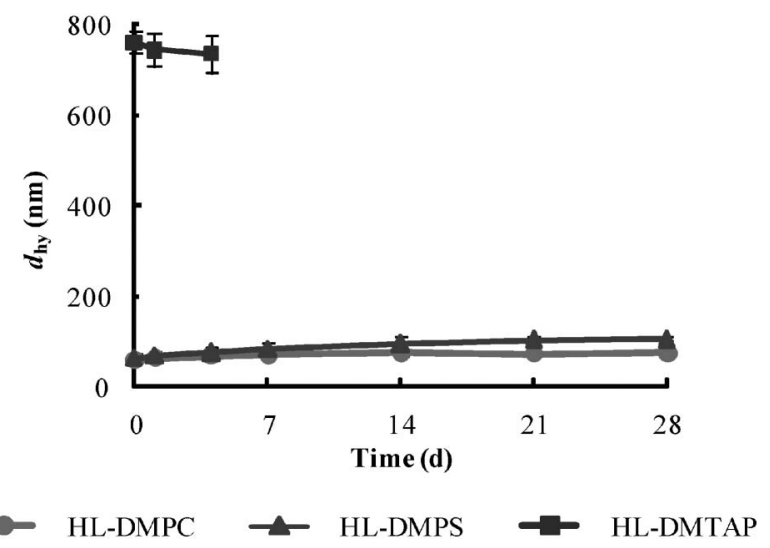

Fig. 3. Time Courses of $d_{\text {hy }}$ for $\mathrm{HL}$ at $25^{\circ} \mathrm{C}$

$[$ lipids $]=1 \mathrm{mM},\left[\mathrm{C}_{12}(\mathrm{EO})_{23}\right]=111 \mu \mathrm{M}$. Data represent the mean \pm S.E. $(n=3)$.

Table 1. Inhibitory Effects of HL on the Growth of SH-SY5Y Cells for $48 \mathrm{~h}$

\begin{tabular}{lcc}
\hline \hline \multicolumn{1}{c}{ Samples } & $\mathrm{IC}_{10}(\mu \mathrm{M})$ & \pm S.E. \\
\hline HL-DMPC & 91 & 4 \\
HL-DMPS & 149 & 20 \\
HL-DMTAP & 54 & 11 \\
\hline
\end{tabular}

Data represent the mean \pm S.E. $(n=3)$.

に示す.

双性の HL-DMPC で処理した細胞では, 経時的 に ThT の蛍光が増し, $\mathrm{A} \beta_{1-40}$ の蓄積が確認され た。アニオン性の HL-DMPS で処理した細胞で は, 観察を行った 90 分間を通して, $\mathrm{A} \beta_{1-40}$ の蓄積 が顕著に抑えられた。 また，カチオン性の HLDMTAP 処理した細胞では，時間経過とともに $\mathrm{A} \beta_{1-40}$ が蓄積する様子が観察され， $\mathrm{A} \beta_{1-40}$ の蓄積を 抑えることはできなかった.

以上の結果より, $\mathrm{A} \beta_{1-40}$ が $\mathrm{HL}$ の持つ電荷との相 互作用で, 細胞への蓄積に差異を生じることが今回 初めて明らかになった。特に，アニオン性 HLDMPS が $\mathrm{A} \beta_{1-40}$ の蓄積を抑制することが確認され た. 
(A)

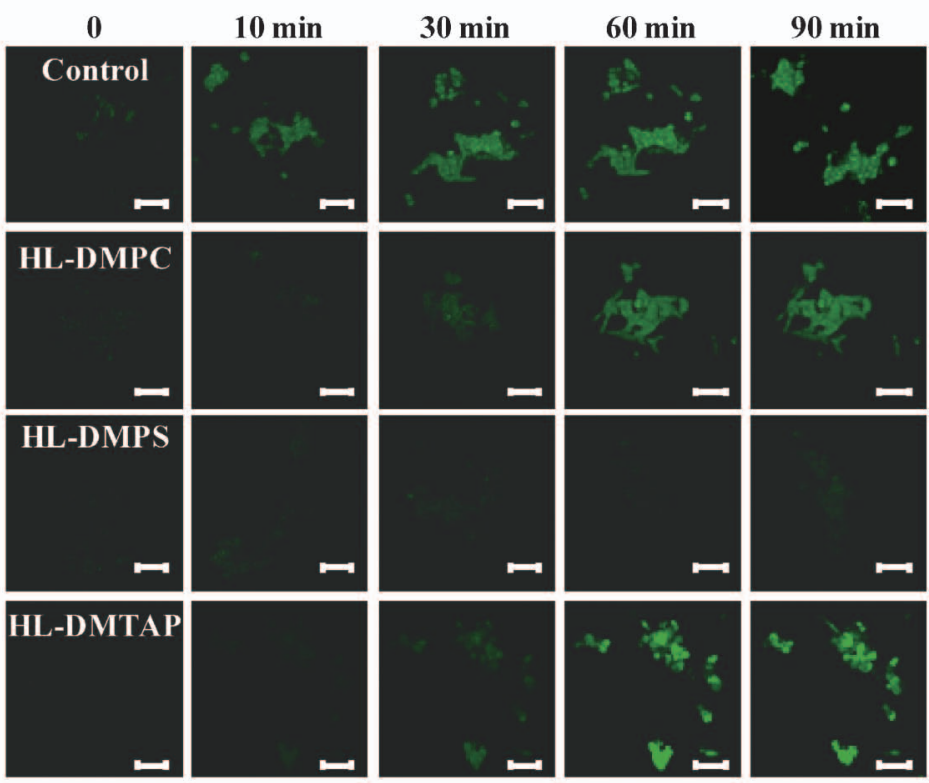

(B)

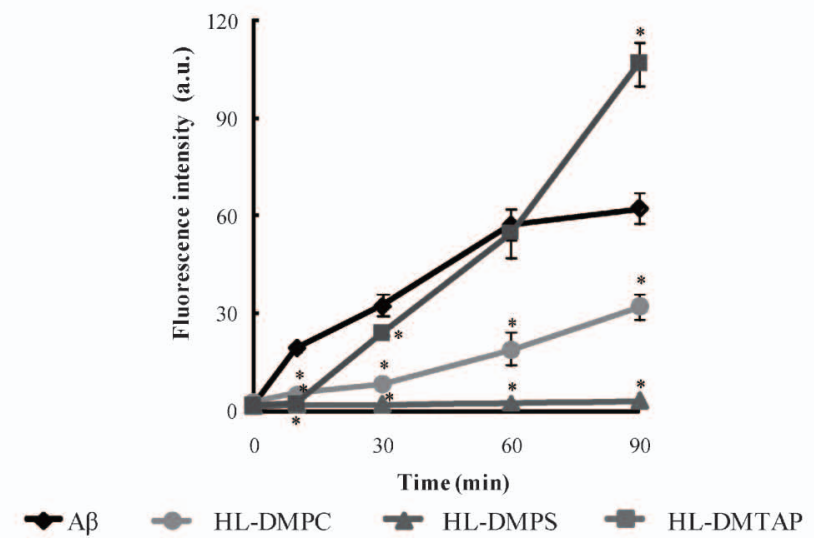

Fig. 4. HL-DMPS Inhibit Accumulation of $\mathrm{A} \beta_{1-40}$ into SH-SY5Y Cells

(A) Fluorescence micrograph images, (B) Fluorescence intensity of SH-SY5Y cells stained with ThT after the treatment with HL. [lipids] $=50 \mu \mathrm{M},\left[\mathrm{C}_{12}\right.$ $\left.(\mathrm{EO})_{23}\right]=5.5 \mu \mathrm{M},\left[\mathrm{A} \beta_{1-40}\right]=20 \mu \mathrm{M},[\mathrm{ThT}]=20 \mu \mathrm{M}$. Scale bars: $20 \mu \mathrm{m}$. Data represent the mean \pm S.E. $(n=4)$. ${ }^{*}$ Significant difference $(p<0.05)$ compared with the $\mathrm{A} \beta_{1-40}$.

\section{SH-SY5Y 細胞へのハイブリッドリポソーム} の蓄積 $\quad 3$ 種類の HL 処理による SH-SY5Y 細胞 への $\mathrm{A} \beta_{1-40}$ の蓄積メカニズムについては，蛍光リ ン脂質（NBDPC）を HL 内に含ませた NBDPC 含 有 HL を用い，フローサイトメーターを用いて取 り込み量を検討した。結果を Fig. 5 に示す。双性 の HL-DMPC，アニオン性の HL-DMPS 処理した 細胞では，細胞に取り込まれた NBDPCによる蛍 光強度が低く抑えられていたが，カチオン性の HL-DMTAP 処理では, 添加直後から NBDPCに よる蛍光強度が高まり，細胞に取り込まれ易いこと が明らかになった。
5. ハイブリッドリポソームの凝集体形成への影 響電荷の異なる $\mathrm{HL}$ と $\mathrm{A} \beta_{1-40}$ の静電的な相互 作用について, $\mathrm{HL}$ 溶液中での $\mathrm{A} \beta_{1-40}$ 凝集体形成を ThT の蛍光検出によって検証した。結果を Fig. 6 に示す。本実験では，コントロールに $\mathrm{A} \beta_{1-40}$ の $\operatorname{PBS}(-)$ 溶液を用いた。コントロールと比較して, 双性の HL-DMPC 溶液中では ThT の蛍光が増して おり， $\mathrm{A} \beta_{1-40}$ 凝集体が形成されていることが示され た $(p<0.05)$.さらに，アニオン性の HL-DMPS 溶液では，ThT の蛍光強度の増加が著しく，より 多くの $\mathrm{A} \beta_{1-40}$ 凝集体が形成されていると考えられ る $(p<0.05)$. 一方, カチオン性の HL-DMTAP 


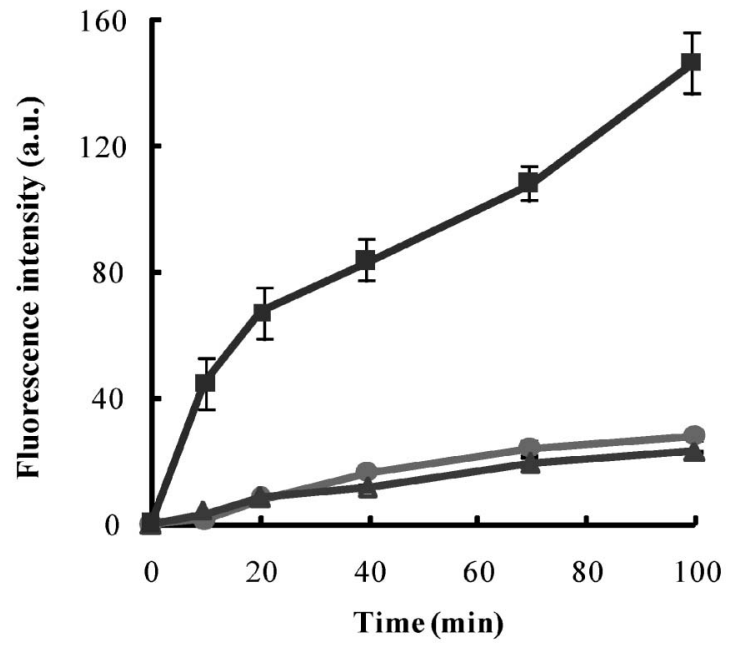

HL-DMPC

HL-DMPS

HL-DMTAP

Fig. 5. Fluorescence Intensity of HL Including NBDPC in SH-SY5Y Cells

[lipids $]=50 \mu \mathrm{M},\left[\mathrm{C}_{12}(\mathrm{EO})_{23}\right]=5.8 \mu \mathrm{M},[\mathrm{NBDPC}]=0.46 \mu \mathrm{M}$. Data represent the mean \pm S.E. $(n=3)$.

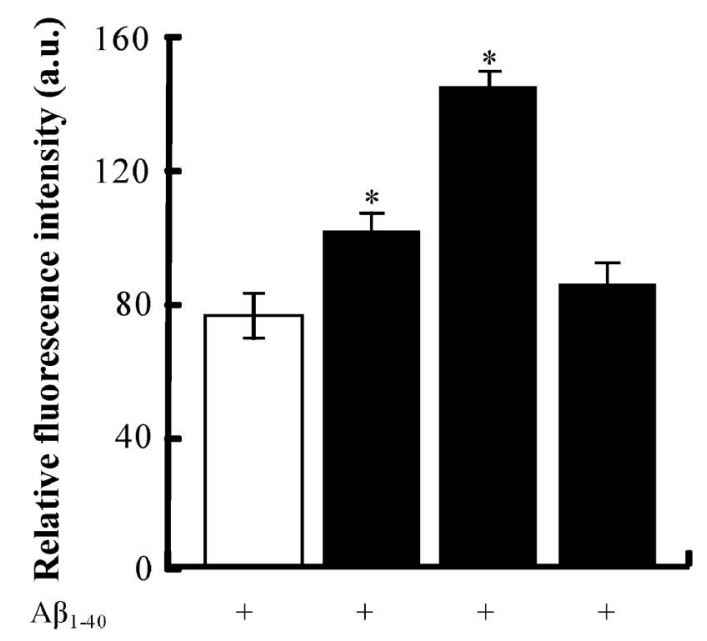

HL-DMPC

HL-DMPS

HL-DMTAP

Fig. 6. Effects of HL on $\mathrm{A} \beta_{1-40}$ Aggregation on the Basis of Fluorometric ThT Assay

$[1$ ipids $]=50 \mu \mathrm{M},\left[\mathrm{C}_{12}(\mathrm{EO})_{23}\right]=5.5 \mu \mathrm{M},\left[\mathrm{A} \beta_{1-40}\right]=20 \mu \mathrm{M},[\mathrm{ThT}]=10$ $\mu$ M. Data represent the mean \pm S.E. $(n=3)$. ${ }^{*}$ Significant difference $(p<$ $0.05)$ compared with the $\mathrm{A} \beta_{1-40}$.

溶液中では，有意な ThT の蛍光強度の増大がみら れず，コントロールと同等であった。先の HL の SH-SY5Y 細胞への取り込み量の解析結果より, ア ニオン性の HL-DMPS は, 細胞に取り込まれ難い

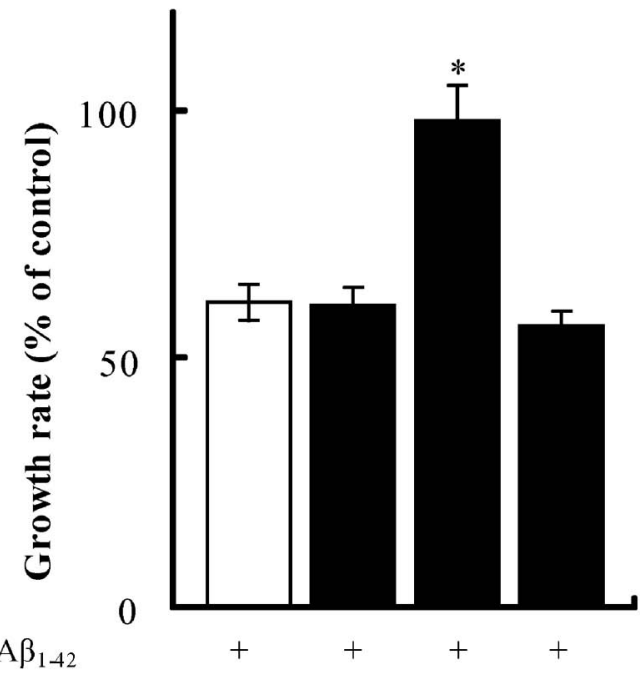

HL-DMPC

HL-DMPS

HL-DMTAP

Fig. 7. Effects of $\mathrm{HL}$ on $\mathrm{A} \beta_{1-42}$ Cytotoxicity

$[$ lipids $]=25 \mu \mathrm{M}, \quad\left[\mathrm{C}_{12}(\mathrm{EO})_{23}\right]=2.3 \mu \mathrm{M},\left[\mathrm{A} \beta_{1-42}\right]=10 \mu \mathrm{M}$. Data represent the mean \pm S.E. $(n=3)$. ${ }^{*}$ Significant difference $(p<0.05)$ compared with the $\mathrm{A} \beta_{1-42}$.

ことから（Fig. 5), HL-DMPS が $\mathrm{A} \beta_{1-40}$ を捕捉し， 細胞への蓄積を防ぐ可能性が示唆される，既に，石 英スライドガラスを用いたモデル膜実験23)におい て, 負の電荷を持ったガラス表面では, $\mathrm{A} \beta_{1-40}$ の凝 集体形成が起こることが報告されており，本実験の 結果と類似している。また，HL-DMPS は，SHSY5Y 細胞に融合し難いことから，HL-DMPS 溶液 中で形成された $\mathrm{A} \beta_{1-40}$ の凝集体を捕捉するように して, 細胞に蓄積するのを防いでいることが考えら れる。

$\mathrm{AD}$ において，実際に患者の血清中の $\mathrm{A} \beta_{1-40}$ 濃度 が高まる24)ことから，アニオン性ハイブリッドリポ ソーム（HL-DMPS）が血液中の $\mathrm{A} \beta_{1-40}$ を除去し， 細胞への蓄積を防ぐ治療薬としての可能性が期待で きる.

\section{6. $\mathrm{A} \boldsymbol{\beta}$ の細胞毒性に対する HL の影響}

$\mathrm{AD}$ において, $\mathrm{A} \beta$ の異常な凝集は細胞毒性を持つこと が知られている. ${ }^{2)}$ 本実験では, HL 処理が $\mathrm{A} \beta$ の持 つ細胞毒性に与える影響について，トリパンブルー 色素排除法によって細胞数を計測し，検討した。な お，実験には， $\mathrm{A} \beta_{1-40}$ よりも毒性の高い $\mathrm{A} \beta_{1-42}{ }^{21)}$ を 用いた。結果を Fig. 7 に示す。細胞に $\mathrm{A} \beta_{1-42}$ を添 
加することで，細胞増殖が抑制されることが示され た。双性の HL-DMPC 及びカチオン性の HLDMTAP 処理によっては $\mathrm{A} \beta_{1-42}$ による細胞増殖抑 制作用を回復する効果はみられなかつた（ $p<$ 0.05)。一方，アニオン性の HL-DMPS 処理によっ て，細胞の増殖は，コントロールと同等にまで回復 した．以上の結果より，アニオン性の HL-DMPS は， $\mathrm{A} \beta$ の細胞への蓄積を抑えることで，細胞毒性 を抑える可能性が明らかになった。実際の ADに おいて，血漿 $\mathrm{A} \beta$ の増加は $\mathrm{AD}$ 発症のリスクが高ま

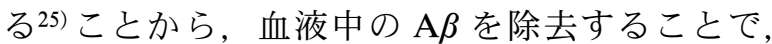
$\mathrm{AD}$ 発症を防ぐという新たな医療素材として期待で きる.

\section{結訔}

本研究は， $\mathrm{AD}$ モデル細胞として用いられている ヒト神経芽腫（SH-SY5Y）細胞を使用し，親水基 の電荷の異なる脂質からなる $\mathrm{HL}$ を用いて, $\mathrm{A} \beta_{1-40}$ 蓄積抑制効果並びにメカニズムについて検討した. その結果，以下の知見が得られた.

（1）双性の HL-DMPC，アニオン性の HL-DMPS は, 直径 $100 \mathrm{~nm}$ 付近の安定した膜を長期間維持 した.

（2）アニオン性の HL-DMPS 処理した SH-SY5Y 細胞において， $\mathrm{A} \beta_{1-40}$ の蓄積を抑制することが確 認され， $\mathrm{A} \beta_{1-40}$ が HL の持つ電荷との相互作用 で，細胞への蓄積に差異を生じることが今回初め て明らかになった。

（3） HL の SH-SY5Y 細胞への取り込み量を測定 したところ，カチオン性の HL-DMTAP は細胞 内に取り込まれ易いことが明らかになった。

(4) $\mathrm{HL}$ 溶液中での $\mathrm{A} \beta_{1-40}$ 凝集体形成について, アニオン性の HL-DMPS 溶液では, ThT の蛍光 強度が高まり， $\mathrm{A} \beta_{1-40}$ との凝集体を形成すること が示された。一方，双性の HL-DMPC 及びカチ オン性の HL-DMTAP では，A $\beta_{1-40}$ 溶液とほぼ 同等の蛍光強度を示した。

（5） $\mathrm{A} \beta_{1-40}$ よりも毒性の強い $\mathrm{A} \beta_{1-42}$ の細胞毒性 に対する $\mathrm{HL}$ 処理の影響については，アニオン 性の HL-DMPS が，SH-SY5Y 細胞の増殖を回復 させることが明らかになった。

以上の結果より，HL の素材に用いた脂質の電荷 の違いが $\mathrm{A} \beta_{1-40}$ の細胞への蓄積に影響を及ぼすこ
とが，今回初めて明らかになった。中でも，アニオ ン性の HL-DMPS 処理によって, 細胞への $\mathrm{A} \beta_{1-40}$ の蓄積が顕著に抑えられ， $\mathrm{AD}$ 治療薬としての可能 性が示された。また，HL-DMPS は，SH-SY5Y 細 胞に融合し難いことから，HL-DMPS 溶液中で形 成された $\mathrm{A} \beta_{1-40}$ の凝集体を捕捉するようにして, 細胞に蓄積するのを防いでいることが考えられる. さらに，HL-DMPS は A $\beta_{1-42}$ の毒性から細胞を保 護するはたらきがあることも明らかになつた，実際 の $\mathrm{AD}$ において，血漿 $\mathrm{A} \beta$ の増加は $\mathrm{AD}$ 発症のリス クが高まることが報告されている. ${ }^{25)}$ アミロイドカ スケード仮説に基づく $\mathrm{AD}$ 発症のメカニズムに鑑 み，血液中の $\mathrm{A} \beta$ を除去することで， $\mathrm{AD}$ 発症を防 ぐという新たな医療素材への展開が期待できる．今 後，アルツハイマーモデル動物を用い，HL-DMPS による治療効果及び体内動態を明確にする.

\section{REFERENCES}

1) Hardy J., Selkoe D. J., Science, 297, 353-356 (2002)

2) Edagawa Y., Journal of Human Environmental Engineering, 5, 138-147 (2003).

3) Yanagisawa K., Okada A., Suzuki N., Nat. Med., 1, 1062-1066 (1995).

4) Sugimoto H., Imamura Y., Yamanishi Y., Yamatsu K., J. Med. Chem., 38, 4821-4829 (1995) .

5) Ueoka R., Moss R. A., Matsumoto Y., Straus G., Murakami Y., J. Am. Chem. Soc., 107, 2185-2186 (1985).

6) Ueoka R., Matsumoto Y., Moss R. A., Swarup S., Sugii A., Harada K., Kikuchi J., Murakami Y., J. Am. Chem., Soc., 110, 1588 -1595 (1988).

7) Ueoka R., Matsumoto Y., Yoshino T., Hirose T., Kikuchi J., Murakami Y., Chem. Lett., 15 127-131 (1986)

8) Matsumoto Y., Imamura C., Ito T., Taniguchi C., Ueoka R., Biol. Pharm. Bull., 18, 1456-1458 (1995).

9) Nagami H., Nakano K., Ichihara H., Matsumoto Y., Ueoka R., Bioorg. Med. Chem. Lett., 16, 782-785 (2006).

10) Nakano K., Iwamoto Y., Takata W., Matsumoto Y., Ueoka R., Bioorg. Med. Chem. Lett., 12, 3251-3254 (2002). 
11) Matsumoto Y., Iwamoto Y., Matsushita T., Ueoka R., Int. J. Cancer, 115, 377-382 (2005).

12) Komizu Y., Matsumoto Y., Ueoka R., Bioorg. Med. Chem. Lett., 16, 6131-6134 (2006).

13) Kitamura I., Kochi M., Matsumoto Y., Ueoka R., Kuratsu J., Ushio Y., Cancer Res., 56, 3986-3992 (1996).

14) Ueoka R., Matsumoto Y., Kanno A., Tsuzaki K., Ichihara H., Biol. Pharm. Bull., 23, 12621263 (2000).

15) Ichihara H., Nagami H., Yamamoto K., Matsumoto Y., Ueoka R., Yakugaku Zasshi, 123, 25-34 (2003).

16) Ichihara H., Nagami H., Kiyokawa T., Matsumoto Y., Ueoka R., Anticancer Res., 28, 1187-1196 (2008).

17) Komizu Y., Tomonaga Y., Goto K., Ueoka R., Bioorg. Med. Chem. Lett., 17, 613-616 (2007).

18) Elworthy P. H., Macfarlane C. B., J. Chem. Soc., 537-541 (1962).
19) Tominaga H., Ishiyama M., Ohseto F., Sasamoto K., Hamamoto T., Suzuki K., Watanabe M., Anal. Commun., 36, 47-50 (1999).

20) Ashwini S. P., Israel R., Hayat O., Peptides, 27, 2858-2866 (2006).

21) Wei W., Wang X., Kusiak J. W., J. Biol. Chem., 277, 17649-17656 (2002).

22) Huang S. K., Lee K. D., Hong K., Friend D. S., Papahadjopoulod D., Cancer Res., 52, 5135-5143 (1992).

23) Ban T., Moriguchi K., Yagi H., Kawasaki T., Kobayashi A., Yuba S., J. Biol. Chem., 281, 33677-33683 (2006).

24） Graff-Radford N. R., Crook J. E., Lucas J., Boeve B. F., Knopman D. S., Ivnik R. J., Smith G. E., Younkin L. H., Peterson R. C., Younkin S. G., Arch. Neurol., 64, 354-362 (2007).

25) van Oijen M., Hofman A., Soares H. D., Koudstaal P., Breteler M. M., Lancet Neurol., 5, 655-660 (2006). 